\title{
Determination of Vitamin E Levels in Walnuts (Juglans regia L.) Grown in the Lake Van Basin by HPLC
}

\author{
Faruk DEMİRKAN* @ Mustafa BİLİCI @ İbrahim Hakkı YÖRÜK @
}

Van Yüzüncü Y1l University, Faculty of Science, Biochemistry, Van, TURKEY

*Corresponding Author: fdemirkan@ hotmail.com

Received Date: 16.11 .2020

Accepted Date: 19.03.2021

Abstract

Aim of study: The present study describes determination of vitamin E levels in Walnuts (Juglans regia

L.) Grown in the Lake Van basin.

Area of study: Adilcevaz, Bahçesaray, Çatak, Edremit, Gevaş regions in the Lake Van basin and in the center of Van.

Material and methods: Walnuts were collected regions and stored in a deep freezer for analysis. On the day of analysis, 10 pieces of fresh and dried walnut samples belonging to each region were taken and broken, and a homogeneous mixture was obtained by pulverizing them and determined by HPLC.

Main results: The amounts of $\alpha$-Tocopherol of the samples in fresh walnuts were found to be $2.36 \pm$ $0.01 \mu \mathrm{g} / \mathrm{g}, 5.01 \pm 0.31 \mu \mathrm{g} / \mathrm{g}, 6.23 \pm 0.15 \mu \mathrm{g} / \mathrm{g}, 7.20 \pm 0.28 \mu \mathrm{g} / \mathrm{g}, 3.99 \pm 0.46 \mu \mathrm{g} / \mathrm{g}, 5.05 \pm 0.30 \mu \mathrm{g} / \mathrm{g}$, respectively, and the amounts of $\gamma$-Tocopherol were found to be $23.80 \pm 0.52 \mu \mathrm{g} / \mathrm{g}, 16.54 \pm 1.08 \mu \mathrm{g} / \mathrm{g}$, $14.82 \pm 0.46 \mu \mathrm{g} / \mathrm{g}, 17.34 \pm 0.78 \mu \mathrm{g} / \mathrm{g}, 11.91 \pm 0.40 \mu \mathrm{g} / \mathrm{g}, 15.57 \pm 0.90 \mu \mathrm{g} / \mathrm{g}$, respectively, according to the regions. The amounts of $\alpha$-Tocopherol in dried walnuts were found to be $5.13 \pm 0.26 \mu \mathrm{g} / \mathrm{g}, 6.84 \pm 0.31$ $\mu \mathrm{g} / \mathrm{g}, 7.58 \pm 0.40 \mu \mathrm{g} / \mathrm{g}, 10.49 \pm 0.51 \mu \mathrm{g} / \mathrm{g}, 8.65 \pm 0.34 \mu \mathrm{g} / \mathrm{g}, 5.82 \pm 0.19 \mu \mathrm{g} / \mathrm{g}$, respectively, and the amounts of $\gamma$-Tocopherol were found to be $33.10 \pm 1.65 \mu \mathrm{g} / \mathrm{g}, 21.97 \pm 0.87 \mu \mathrm{g} / \mathrm{g}, 20.98 \pm 0.83 \mu \mathrm{g} / \mathrm{g}, 29.19 \pm 0.80$ $\mu \mathrm{g} / \mathrm{g}, 21.09 \pm 0.24 \mu \mathrm{g} / \mathrm{g}, 18.41 \pm 0.82 \mu \mathrm{g} / \mathrm{g}$, respectively, according to the regions.

Highlights: The results obtained in the study are considered, it is observed that the walnuts grown in Adilcevaz, Bahçesaray, Çatak, Edremit, Gevaş and Van-Center regions are of high quality.

Keywords: Walnut, Vitamin E, Lake Van basin, HPLC, Tocopherol

\section{Van Gölü Havzasında Yetiştirilen Cevizlerde (Juglans regia L.) Vitamin E Düzeylerinin HPLC ile Belirlenmesi}

$\ddot{O} \mathbf{z}$

Çalı̧̧manın amacı: Bu çalışmada, Van gölü havzasında yetiştirilen cevizlerde (Juglans regia L.) vitamin E seviyelerinin belirlenmesi amaçlanmıştır.

Çalışma alanı: bulunan Adilcevaz, Bahçesaray, Çatak, Edremit, Gevaş yöreleri ile Van merkez.

Materyal ve yöntem: Bölgelerden ceviz örnekleri toplandıktan sonra derin dondurucuda muhafaza edilmiştir. Analiz için, her bir bölgeye ait taze ve kurutulmuş 10 adet ceviz kırılmış ve ufalama yöntemi ile homojen bir karışım haline getirildikten sonra HPLC (Yüksek Performanslı Sıvı Kromatografisi) ile tayin gerçekleştirilmiş̧ir.

Temel sonuçlar: Örneklerin yaş cevizdeki $\alpha$ - Tokoferol miktarları sırasıyla $2.36 \pm 0.01 \mu \mathrm{g} / \mathrm{g}, 5.01$ $\pm 0.31 \mu \mathrm{g} / \mathrm{g}, 6.23 \pm 0.15 \mu \mathrm{g} / \mathrm{g}, 7.20 \pm 0.28 \mu \mathrm{g} / \mathrm{g}, 3.99 \pm 0.46 \mu \mathrm{g} / \mathrm{g}, 5.05 \pm 0.30 \mu \mathrm{g} / \mathrm{g}$ ve $\gamma$-Tokoferol miktarlarıda bölgelere göre sırasıyla $23.80 \pm 0.52 \mu \mathrm{g} / \mathrm{g}, 16.54 \pm 1.08 \mu \mathrm{g} / \mathrm{g}, 14.82 \pm 0.46 \mu \mathrm{g} / \mathrm{g}, 17.34$ $\pm 0.78 \mu \mathrm{g} / \mathrm{g}, 11.91 \pm 0.40 \mu \mathrm{g} / \mathrm{g}, 15.57 \pm 0.90 \mu \mathrm{g} / \mathrm{g}$ olarak bulunmuştur. Araştırmada kuru cevizdeki $\alpha-$ Tokoferol miktarları sirasiyla $5.13 \pm 0.26 \mu \mathrm{g} / \mathrm{g}, 6.84 \pm 0.31 \mu \mathrm{g} / \mathrm{g}, 7.58 \pm 0.40 \mu \mathrm{g} / \mathrm{g}, 10.49 \pm 0.51$ $\mu \mathrm{g} / \mathrm{g}, 8.65 \pm 0.34 \mu \mathrm{g} / \mathrm{g}, 5.82 \pm 0.19 \mu \mathrm{g} / \mathrm{g}$ ve $\gamma$-Tokoferol miktarlarıda bölgelere göre $33.10 \pm 1.65 \mu \mathrm{g} / \mathrm{g}$, $21.97 \pm 0.87 \mu \mathrm{g} / \mathrm{g}, 20.98 \pm 0.83 \mu \mathrm{g} / \mathrm{g}, 29.19 \pm 0.80 \mu \mathrm{g} / \mathrm{g}, 21.09 \pm 0.24 \mu \mathrm{g} / \mathrm{g}, 18.41 \pm 0.82 \mu \mathrm{g} / \mathrm{g}$ olarak tespit edilmiştir.

Araştırma vurguları: Elde edilen sonuçlar incelendiğinde, Adilcevaz, Bahçesaray, Çatak, Edremit, Gevaş and Van-Merkez bölgelerinde yetişen cevizlerin yüksek kalitede olduğu belirlenmiştir.

Anahtar kelimeler: Ceviz, Vitamin E, Van gölü havzası, HPLC, Tokoferol 


\section{Introduction}

Human beings need to take fat, protein, carbohydrate, vitamins and minerals in a sufficient and balanced way to maintain their life in a healthy manner. While different foodstuffs of vegetable and animal origin contain these components at different ratios, there are not many foodstuffs that contain all of these components at a balanced level. Most of the nuts and especially walnuts are rich in these essential nutrients. Since the composition of the walnut depends on many factors such as variety, climate and soil characteristics, harvest time, irrigation, fertilization, disease and pest control, the data determined by the researchers working in this field differ. Recently, there have been several reported studies about walnuts characteristics. The studies have focused on minor components due to their influence on walnuts quality. The most important countries in the world producing walnuts are China, USA, Iranian, and Turkey (Aydin et al., 2007) Walnuts are an important source of vitamin E due to high content of tocopherols. Total tocopherol concentration differs from 194 to $297 \mathrm{mg} / \mathrm{kg}$ in walnuts (Miller \& Yang, 1985; Ferhatoğlu, 1999, 2001; Rabadán et al., 2019; Kazankaya \& Güvenç, 2019). In addition to its rich oil content and qualified fatty acid composition in terms of human health, the fact that walnut oil has the highest tocopherol content after wheat embryo strengthens the importance of this valuable fruit. While the $\alpha$ , $\gamma$-, and $\delta$ - tocopherol content of walnut oil was determined as 536, 595 and $450 \mathrm{mg} / \mathrm{kg}$, respectively, its Vitamin E activity was evaluated as $636 \mathrm{mg} / \mathrm{kg}$ (Paunovic, 1990; Kazankaya \& Güvenç, 2019). While there is information indicating that walnut was used for medical purposes in ancient periods and is especially good for wounds, it has been determined that it is also included in the composition of cosmetic products due to its moisturizing properties. The use of walnut in cosmetic products is mainly attributed to its linoleic and linolenic acid content. These acids are known to have a role in regulating the water permeability of the skin (Strila et al., 1998; S Sen et al., 2006). Nowadays, there are 3 important walnut varieties, including Juglans regia L., Juglans nigra L. and Juglans cinerea $L$.. Apart from them, many other varieties are also found. The products exported in the world are divided into five main groups according to their factor intensity, which are R\&D based products that are easy and difficult to imitate, in addition to raw material, labor and capital intensive ones (Erkan et al., 2015; Kazankaya \& Güvenç 2019). Juglans regia (Anatolian walnut, Persian walnut) variety is widely grown in our country. Lake Van basin is also among the important walnut growing regions of Anatolia (Kazankaya et al., 2003). The first thing that comes to mind when it comes to human nutrition is three main food groups. As is known, they are fats, proteins and carbohydrates. The ability of a person to have a healthy structure and to protect his/her health depends on his/her balanced nutrition in terms of basic foodstuffs. In order to determine the place of walnut in this balanced nutrition, it will be necessary to reveal its composition and its nutritional value depending on this composition. Therefore, herein, we aimed to determine vitamin $\mathrm{E}$ levels in Walnuts (Juglans regia L.) Grown in the Lake Van basin by HPLC.

\section{Material and Methods}

The walnuts collected from various regions of the Lake Van basin were brought to the laboratory by marking according to the regions and stored in a deep freezer for analysis. On the day of analysis, 10 pieces of fresh and dried walnut samples belonging to each region were taken and broken, and a homogeneous mixture was obtained by pulverizing them. Then, 1 gram of this mixture was weighed on a precision scale and 6 samples were created separately for each region, both fresh and dried.

\section{Collection of Materials and Analysis}

The extraction method specified by Miller \& Yang (1985) was adapted according to our laboratory conditions and the procedures were performed to determine the vitamin E levels of the samples obtained from walnuts collected from various regions of the Lake Van basin. Then, the methanol water mixture $(98: 2 \mathrm{v} / \mathrm{v})$ was prepared to be used as mobile phase in HPLC. The UV detector (DAD) was set to a wavelength of $290 \mathrm{~nm}$ for reading, and the peaks of these standards were taken with 
the previously prepared $\alpha$ and $\gamma$-tocopherol standard solutions on the HPLC device at a flow rate of $1.5 \mathrm{ml} / \mathrm{min}$. Vitamin $\mathrm{E}$ amounts of walnut samples were determined by comparing the $\alpha$ and $\gamma$-tocopherol peaks taken with the peak areas of the standard solutions (Zaspel \& Csallany, 1983).

\section{Statistical Analysis}

In the study, the Kruskal-Wallis test was used to determine whether there was a difference between the regions in terms of vitamin $\mathrm{E}$ content in walnuts due to the low number of repetitions and the lack of normal distribution of the data. As a result of the analysis of variance, the Mann-Whitney U test was applied to determine the districts where there was a difference between the vitamin $\mathrm{E}$ contents of walnuts grown there (Champe \& Harvey, 1997). In the study, arithmetic mean was used instead of mean rank statistics in the tables for a better understanding of interpretations.

\section{Results and Discussion}

The selection studies carried out in recent years have enabled the cultivation of varieties unique to Turkey (Kazankaya et al., 2003; Zaspel \& Csallany, 1983). Furthermore, it was determined that that the antioxidant vitamin levels in the plants growing in high altitude regions were higher compared to the plants grown in low altitude regions (Sze-Tao et al., 2000; Özkan, 1993; Aslan, 1985). The fatty acid composition, oil content and some other quality characteristics of 9 different walnut species grown in Turkey's different regions were examined, and it was determined that the ratio of the fat content to the kernel walnut weight varied between 54.68-62.28\%, the main saturated fatty acid was palmitic acid, followed by stearic acid, and oleic acid was the unsaturated fatty acid containing a double bond. The mostfatty acid is linoleic acid, it was determined that it constituted $53.68-60.09 \%$ of the total fatty acid in walnuts and that linolenic acid varied between 7.77$15.35 \%$ in walnuts (Ağar et al., 1995; Padley et al.,1995).

In this study, the amounts of vitamin $\mathrm{E}$ in walnuts taken from Adilcevaz, Bahçesaray, Çatak, Edremit, Gevaş and Van-Center regions of the Lake Van basin, which is among the most important walnut growing regions of Turkey, were determined. The amounts of $\alpha$-Tocopherol of the samples in fresh walnuts were found to be $2.36 \pm 0.01$ $\mu \mathrm{g} / \mathrm{g}, 5.01 \pm 0.31 \mu \mathrm{g} / \mathrm{g}, 6.23 \pm 0.15 \mu \mathrm{g} / \mathrm{g}, 7.20$ $\pm 0.28 \mu \mathrm{g} / \mathrm{g}, 3.99 \pm 0.46 \mu \mathrm{g} / \mathrm{g}, 5.05 \pm 0.30$ $\mu \mathrm{g} / \mathrm{g}$, respectively, and the amounts of $\gamma$ Tocopherol were found to be $23.80 \pm 0.52$ $\mu \mathrm{g} / \mathrm{g}, 16.54 \pm 1.08 \mu \mathrm{g} / \mathrm{g}, 14.82 \pm 0.46 \mu \mathrm{g} / \mathrm{g}$, $17.34 \pm 0.78 \mu \mathrm{g} / \mathrm{g}, 11.91 \pm 0.40 \mu \mathrm{g} / \mathrm{g}, 15.57 \pm$ $0.90 \mu \mathrm{g} / \mathrm{g}$, respectively, according to the regions (Figure 1).

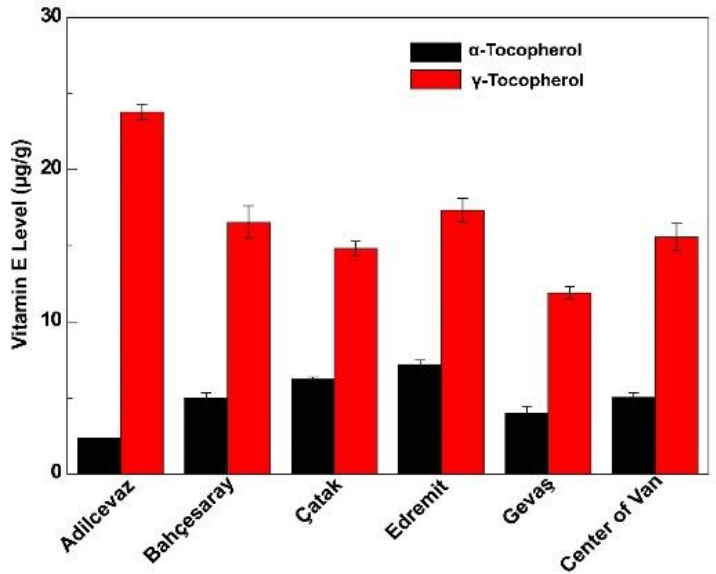

Figure 1. Statistical results of Vitamin E levels in fresh walnuts of the regions (sample number: 6, the difference between the different lettered area means is statistically significant $(\mathrm{p}<0.05))$

In the study, the amounts of $\alpha$-Tocopherol in dried walnuts were found to be $5.13 \pm 0.26$ $\mu \mathrm{g} / \mathrm{g}, 6.84 \pm 0.31 \mu \mathrm{g} / \mathrm{g}, 7.58 \pm 0.40 \mu \mathrm{g} / \mathrm{g}$, $10.49 \pm 0.51 \mu \mathrm{g} / \mathrm{g}, 8.65 \pm 0.34 \mu \mathrm{g} / \mathrm{g}, 5.82 \pm$ $0.19 \mu \mathrm{g} / \mathrm{g}$, respectively, and the amounts of $\gamma$ Tocopherol were found to be $33.10 \pm 1.65$ $\mu \mathrm{g} / \mathrm{g}, 21.97 \pm 0.87 \mu \mathrm{g} / \mathrm{g}, 20.98 \pm 0.83 \mu \mathrm{g} / \mathrm{g}$, $29.19 \pm 0.80 \mu \mathrm{g} / \mathrm{g}, 21.09 \pm 0.24 \mu \mathrm{g} / \mathrm{g}, 18.41 \pm$ $0.82 \mu \mathrm{g} / \mathrm{g}$, respectively, according to the regions (Figure 2). 


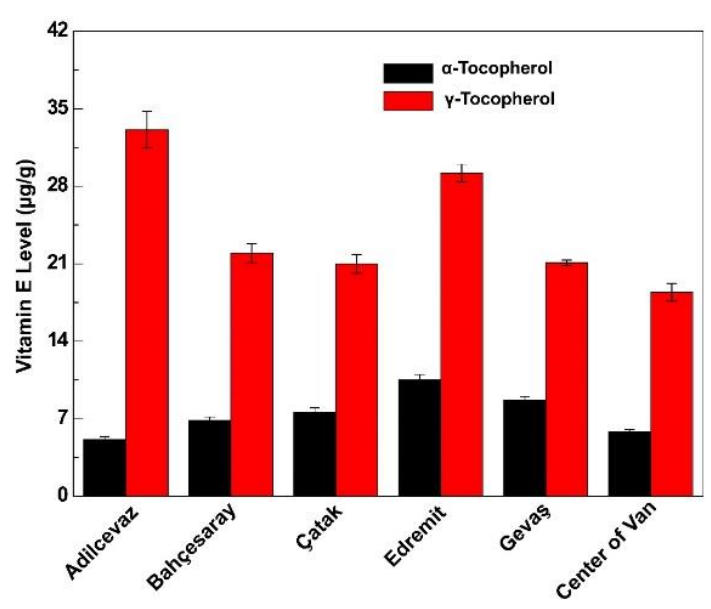

Figure 2. Statistical results of Vitamin E levels in dried walnuts of the regions (sample number: 6, the difference between the different lettered area means is statistically significant $(\mathrm{p}<0.05))$.

\section{Conclusion}

HPLC method is one of the techniques successfully applied in the analysis of tocopherol in oil. The separation of the mixtures, recognition of components and their quantities can be performed precisely and in a short time. The method provides better results than colorimetric and other electrochemical methods. In this study, the amounts of $\gamma$ tocopherol in dried and fresh walnuts in Adilcevaz region were found to be higher compared to other regions. Our results are in parallel with a previous study (Küçük et al., 2003). The vitamin content of a plant variety depends on many factors. Climate conditions and ecological conditions can be listed as the main factors. The amount of antioxidant vitamins produced by the plant also changes due to reasons such as climate type, high or low altitude, soil type and structure, and exposure to radioactive. We considered that altitude and climatic conditions were among the factors that played a role in this difference in the Lake Van basin. We do not have enough information on whether taking vitamins required for sports performance in large quantities has a positive effect on performance. It is known that the lack of minerals and vitamins negatively affects the performance and the intake of minerals and vitamins from outside affects it positively. Vitamins that play a role in biochemical events are used in required amounts in our body to sustain these events.

When the results obtained in the study are considered, it is observed that the walnuts grown in Adilcevaz, Bahçesaray, Çatak, Edremit, Gevaş and Van-Center regions are of high quality. In this context, it has been concluded that focusing on the selection of walnuts in these regions and concentrating on the production of standard varieties that are compatible with the conditions of our country may significantly contribute to the national economy and science.

\section{Ethics Committee Approval N/A}

\section{Peer-review}

Externally peer-reviewed.

\section{Author Contributions}

Conceptualization: F.D., M.B., I.H.Y.; Investigation: F.D., M.B.; Material and Methodology: F.D., M.B.; Supervision: F.D., I.H.Y.; Visualization: F.D., M.B; WritingOriginal Draft: F.D, M.B.; Writingreview\&Editing: F.D. All authors have read and agreed to the published version of manuscript.

\section{Conflict of Interest}

The authors have no conflicts of interest to declare.

\section{Funding}

The authors declared that this study has received no financial support.

\section{References}

Ağar, İ.T., Garcia, J.M., Kafkas, S. \& Kaşka, N., (1995). Anadolu'nun değişik bölgelerinden selekte edilmiş değişik ceviz tipleriyle standart Türk çeşitlerinin yağ asitleri kompozisyonları. Türkiye II. Ulusal Bahçe Bitkileri Kongresi, 479-482, Adana.

Aslan, S. (1985). Modern teşhis ilaç ve tedavi. İstanbul: Beta Basım Yayın Dağıtım.

Aydın A., Yıldırım, İ., Akyüz, K. C. \& Üçüncü K., 2007. Bazı odundışı orman ürünlerinin üretim, ithalat ve ihracat projeksiyonları, Journal of Forestry Faculty, Kastamonu University, 7, 124-139. 
Champe, P.C. \& Harvey, R.A. (1997). Lippincott's illustrated rewievs serisinden: Biyokimya. İstanbul: Nobel Tip Kitapevleri.

Colombini, M., Vanoni, M.C. \& Amelotti, G., (1979). Olio di noci, nocciole, mandorle, avacado, composizione sterolica, Rive. Ita. Sost. Grasse, 56, 392-393.

Erkan, B., Arpacı, B.B., Yaralı, F. \& Güvenç, İ. (2015). Türkiye'nin sebze ihracatında karşılaştırmalı üstünlükleri. KSÜ Doğa Bil. Dergisi, 18(4), 70-76.

Ferhatoğlu, Y. (1999) Ceviz yetiştiriciliğinin genel prensipleri. Yalova: Atatürk Bahçe Kültürleri Merkez Araştırma Enstitüsü, Yayın No:78.

Ferhatoğlu, Y., (2001). Ceviz yetiştiriciliği. Ankara: Tarım ve Köyişleri Bakanlığı Teşkilatlanma ve Destekleme Genel Müdürlüğü Yayım Dairesi Başkanlığı.

Miller, K.W. \& Yang, C.S., (1985). An isocratic high-performance liquid chromatography method for the simultaneous analysis of plasma retinol, $\alpha$-tocopherol and various carotenoids. Analytical Biochemistry, 145, 21-26.

Kazankaya, A., Şahinbaş, T., Yılmaz, M. \& Tekintaş, F.E., (2003). Çatak yöresi cevizlerinin meyve özellikleri. Türkiye IV. Ulusal Bahçe Bitkileri Kongresi, Akdeniz Üniversitesi Ziraat Fakültesi Bahçe Bitkileri Bölümü, 08-12 Eylül, Antalya, 144-146.

Güvenç, İ. \& Kazankaya, A. (2019). Türkiye'de ceviz üretimi, dış ticareti ve rekabet gücü, Yüzüncü Yll Üniversitesi Tarım Bilimleri Dergisi, 29(3), 418-424.

Küçük, M., Kazankaya, A., Y1lmaz, M., Cavidoğlu, İ. \& Balta, F., (2003). Doğu Anadolu bölgesinde yetiştirilen cevizlerin (Juglans regia L.) meyve özellikleri, yağ içerikleri ve yağ asidi kompozisyonları. Türkiye IV. Ulusal Bahçe Bitkileri Kongresi.

Padley, F.B., Gunstone, F.D. \& Harwood, J.L., (1995). Ocuurance and characteristics of oils and fats. In: Lipid Handbook. Chapmann \& Hall, 2-6 Boundry Row, London, SE1 8HN, UK.

Paunovic, S.A., (1990). The walnut cultivars selected from indigenous population of the Juglans Regia L. In Sr Serbia, Sfr Yugoslavia. Acta Hort., 284, 135-142.

Rabadán, A., Álvarez-Ortí, M. \& Pardo, J. (2019). A comparison of the effect of genotype and weather conditions on the nutritional composition of most important commercial nuts. Scientia Horticulturae, 244, 218-224

Özkan, Y. (1993). Tokat merkez ilçe cevizlerinin (Juglans Regia L.) seleksiyon yoluyla islahı üzerinde araştırmalar. Doktora tezi. Yüzüncü Y1l Üniversitesi Fen Bilimleri Enstitüsü, Van.
Sze-Tao, K. W.C. \& Sahte, S.K., (2000). Walnuts (Juglan regia L): proximate composition. protein solobility, Protein amino acid compposition and protein in vitro digestibility. Journal of the science of Food and Agriculture

Şen, S.M., Doğan, A., Kazankaya, A. \& Yarılgaç, T., (2006). Bahçeden Mutfağa Ceviz. Moji Yayınları, Ankara, Turkey.

Strila, T.Y., Melnichik, G.G. \& Boltivets, V.S., (1998). Quality characteristics of the fruit of some forms of Juglans Regia L. Hort. Abst., 58(9), 606-5525.

Zaspel, B.J. \& Csallany, S. (1983). Determination of alpha-tocopherol in tissues and plasma by high-performance liquid chromatography. Analytical Biochemistry, 130,146-150. 